\title{
PENGARUH MOTIVASI KERJA DAN KOMPENSASI TERHADAP KEPUASAN KERJA PADA KARYAWAN PT TRIDAYA ERAMINA BAHARI
}

\author{
Widya Parimita \\ Fakultas Ekonomi Universitas Negeri Jakarta \\ Email: widya_parimita@yahoo.com \\ Siti Khoiriyah \\ Fakultas Ekonomi Universitas Negeri Jakarta \\ Email: sitikhoiriyah1016@gmail.com \\ Agung Wahyu Handaru \\ Fakultas Ekonomi Universitas Negeri Jakarta \\ Email: agung_1178@yahoo.com
}

\begin{abstract}
ABSTRAK
Tujuan penelitian ini adalah: 1) Untuk mengetahui deskripsi motivasi kerja, kompensasi dan kepuasan kerja pada karyawan PT Tridaya Eramina Bahari, 2) Untuk mengetahui apakah terdapat pengaruh antara motivasi kerja terhadap kepuasan kerja pada karyawan pada PT Tridaya Eramina Bahari, 3) Untuk mengetahui apakah terdapat pengaruh antara kompensasi terhadap kepuasan kerja pada karyawan PT Tridaya Eramina Bahari, 4) Untuk mengetahui motivasi kerja dan kompensasi dapat memprediksi kepuasan kerja pada karyawan pada PT Tridaya Eramina Bahari. Penelitian ini dilakukan terhadap 70 karyawan PT Tridaya Eramina Bahari. Teknik pengumpulan data menggunakan metode survey yaitu menyebarkan kuesioner yang kemudian diolah dengan program SPSS 24.0. Penelitian ini menggunakan analisis deskriptif dan eksplanatori. Hasil dari regresi menunjukkan bahwa terdapat pengaruh positif dan signifikan antara motivasi kerja terhadap kepuasan kerja, terdapat pengaruh positif dan signifikan antara kompensasi terhadap kepuasan kerja. Motivasi kerja dan kompensasi dapat memprediksi kepuasan kerja.
\end{abstract}

Kata kunci: Motivasi Kerja, Kompensasi, Kepuasan Kerja 


\section{PENDAHULUAN}

Dalam perkembangan bisnis masa kini dan masa yang akan datang sangat bergantung pada sumber daya manusia yang dimiliki oleh perusahaan. Perusahaan dituntut untuk memiliki sumber daya manusia yang berkompeten sehingga mampu menjadi kekuatan bagi perusahaan untuk bersaing di tengah arus perubahan yang semakin dinamis. Untuk menggerakkan karyawan agar dapat bekerja sesuai dengan yang dikehendaki perusahaan, maka perusahaan harus memahami motivasi karyawan dalam bekerja, karena motivasi inilah yang menentukan perilaku karyawan dalam bekerja.

Setiap karyawan mempunyai kebutuhan dan harapan-harapan tertentu, hal ini harus menjadi perhatian untuk perusahaan. Untuk menghasilkan karyawan yang memiliki kepuasan kerja yang tinggi, perusahaan harus menciptakan kondisi yang dapat mendorong karyawan untuk mengembangkan dan meningkatkan kemampuan maupun keterampilan yang dimiliki secara optimal. Salah satu upaya yang harus ditempuh adalah dengan memberikan kompensasi yang memuaskan.

Karyawan yang memiliki motivasi kerja yang tinggi dan mendapatkan kompensasi yang sesuai dengan usahanya akan menimbulkan rasa kepuasan dalam diri karyawan. Karyawan yang memiliki kepuasan kerja yang tinggi akan sangat berpengaruh dalam kelangsungan hidup perusahaan. Kepuasan kerja karyawan akan terlihat dari bagaimana sikap karyawan terhadap pekerjaannya.

Peneliti sebelumnya telah melakukan pra riset dengan melakukan wawancara. Hasil yang peneliti dapat adalah kepuasan kerja pada karyawan PT Tridaya Eramina Bahari masih terbilang rendah, hal itu dapat dilihat dari tingkat keterlambatan karyawan yang masih tinggi.

Tabel 1. Data Keterlambatan Karyawan Tahun 2016

\begin{tabular}{|c|c|c|c|c|c|c|c|c|c|c|}
\hline Bulan & Jan & Feb & Mar & Apr & Mei & Jun & Jul & Agu & Sep & Okt \\
\hline $\begin{array}{l}\text { Jumlah } \\
\text { Karyawan } \\
\text { Terlambat } \\
\end{array}$ & 14 & 11 & 11 & 9 & 12 & 14 & 10 & 12 & 7 & 4 \\
\hline
\end{tabular}

Dari hasil wawancara, peneliti juga mendapatkan faktor-faktor yang mempengaruhi kepuasan kerja karyawan. Faktor-faktor tersebut diantaranya adalah faktor motivasi 
kerja dan faktor kompensasi. Karyawan yang memiliki tingkat motivasi kerja yang rendah akan terlihat pada sikap dan perilakunya dalam melakukan pekerjaan. Terbukti dari tingkat ketidakhadiran karyawan yang masih tinggi.

Tabel 2. Data Ketidakhadiran Karyawan Tahun 2016

\begin{tabular}{lcccccccccc}
\hline Bulan & Jan & Feb & Mar & Apr & Mei & Jun & Jul & Agu & Sep & Okt \\
\hline Sakit & 3 & 6 & 5 & 10 & 6 & 8 & 6 & 9 & 7 & 6 \\
Izin & 10 & 10 & 11 & 15 & 18 & 6 & 15 & 5 & 12 & 14 \\
Tanpa & & & & & & & & & & \\
Alasan & 20 & 20 & 19 & 16 & 12 & 24 & 19 & 13 & 8 & 11 \\
\hline Sumber: data diolah peneliti, 2017 & & & & & & & &
\end{tabular}

Faktor lain yang dapat menyebabkan terjadinya kepuasan kerja pada karyawan adalah faktor kompensasi. Terdapat dua sistem kompensasi yaitu kompensasi langsung dan kompensasi tidak langsung. Kompensasi langsung yang diberikan berupa gaji pokok dan upah makan, namun tidak terdapatnya kompensasi tidak langsung yang diberikan untuk karyawan. Gaji pokok karyawan yang diberikan sebesar Rp. 2.300.000 dan upah uang makan sebesar Rp. 650.000. Jadi, gaji utuh yang didapatkan karyawan sebesar Rp. 2.950.000. Gaji tersebut masih terbilang rendah karena masih berada dibawah upah minimun regional Jakarta yang ditetapkan.

\section{Pembatasan Masalah}

Pada penelitian ini, peneliti membatasi ruang lingkup penelitian, hal ini dikarenakan agar penelitian lebih terfokus dan dapat disesuaikan dengan permasalahan yang diteliti. Responden yang diambil dalam penelitian ini adalah karyawan pada PT. Tridaya Eramina Bahari yaitu sebanyak 85 karyawan. Selain itu, pembatasan masalah ini dilakukan karena keterbatasan waktu dan kemampuan peneliti.

\section{Rumusan Masalah}

1. Bagaimana deksripsi motivasi kerja, kompensasi, dan kepuasan kerja karyawan PT Tridaya Eramina Bahari?

2. Apakah motivasi kerja berpengaruh terhadap kepuasan kerja karyawan PT Tridaya Eramina Bahari? 
3. Apakah kompensasi berpengaruh terhadap kepuasan kerja karyawan PT Tridaya Eramina Bahari?

4. Apakah motivasi kerja dan kompensasi dapat memprediksi kepuasan kerja pada karyawan pada PT. Tridaya Eramina Bahari?

\section{Tujuan Penelitian}

1. Untuk mengetahui deskripsi motivasi kerja, kompensasi dan kepuasan kerja pada karyawan pada PT Tridaya Eramina Bahari.

2. Untuk mengetahui apakah terdapat pengaruh antara motivasi kerja terhadap kepuasan kerja pada karyawan pada PT Tridaya Eramina Bahari.

3. Untuk mengetahui apakah terdapat pengaruh antara kompensasi terhadap kepuasan kerja pada karyawan PT Tridaya Eramina Bahari.

4. Untuk mengetahui apakah motivasi kerja dan kompensasi dapat memprediksi kepuasan kerja pada karyawan pada PT Tridaya Eramina Bahari.

\section{TELAAH PUSTAKA}

\section{Kepuasan Kerja}

Menurut Janssen dalam Naveed Ahmad et.al (2014:85) "job satisfaction means how employee of an organization feels about work". Yang berarti kepuasan kerja merupakan apa yang karyawan rasakan tentang pekerjaan mereka. Hal ini dapat menimbulkan dampak yang positif atau negatif. Karyawan yang memiliki rasa kepuasan yang tinggi akan menunjukkan perilaku positif terhadap pekerjaan mereka, begitu juga sebaliknya.

George dan Jones dalam Priansa menyatakan (2014:291) "kepuasan kerja merupakan sekumpulan perasaan, keyakinan, dan pikiran tentang bagaimana respon seseorang terhadap pekerjaannya". Yang berarti bahwa kepuasan kerja merupakan sekumpulan perasaan karyawan terhadap pekerjannya, apakah senang atau tidak senang sebagai hasil interaksi dan penilaian karyawan terhadapa pekerjaan dan lingkungan kerjanya.

Berdasarkan definisi dari para ahli, maka dapat disimpulkan pengertian dari kepuasan kerja adalah suatu sikap yang mencerminkan perasaan emosional karyawan yang menyenangkan atau tidak menyenangkan terhadap pekerjaannya., kepuasan kerja 
dapat dilihat dari sikap karyawan terhadap segala sesuatu yang dihadapi di lingkungan kerjanya.

\section{Motivasi Kerja}

Menurut Stokes dalam Kadarisman (2012:278) "motivasi kerja adalah sebagai pendorong bagi seseorang untuk melakukan pekerjaannya dengan baik, juga merupakan faktor yang membuat perbedaan antara sukses dan gagalnya dalam banyak hal dan merupakan tenaga emosional yang sangat penting untuk sesuatu pekerjaan baru”.

Menurut Pinder (2008:11) "work motivation is a set of energic forces that originate both within as well as beyond an individual's being, to initiate work-related and to determine its form, direction, intensity, and duration". Dengan kata lain motivasi kerja adalah sebuah kekuatan yang berasal baik dari dalam maupun luar makhluk individu, untuk memulai pekerjaan dan untuk menentukan bentuk, arah, intensitas, dan durasi pekerjaan yang dilakukan.

Berdasarkan definisi dari para ahli diatas, maka dapat disimpulkan bahwa motivasi kerja adalah suatu daya penggerak yang berasal dari dalam atau luar diri seseorang dalam melakukan sesuatu untuk mencapai tujuan tertentu.

\section{Kompensasi}

Menurut Mutiara S. Panggabean dalam Subekhi dan Jauhar (2012:176) "kompensasi adalah setiap bentuk penghargaan yang diberikan karyawan sebagai balas jasa atas kontribusi yang mereka berikan kepada organisasi”. Pada umumnya kompensasi diberikan untuk menarik karyawan yang berkualitas, mendorong karyawan untuk berprestasi tinggi, dan mempertahan karyawan yang produktif dan berkualitas untuk memiliki loyalitas yang tinggi.

Ranupandojo dalam Mila Badriyah merumuskan (2015:154) "kompensasi merupakan kegiatan pemberian balas jasa kepada pegawai”. Yang berarti bahwa kompensasi diberikan untuk karyawan yang telah memberikan jasanya dalam bekerja untuk kemajuan perusahaan. Kompensasi yang diberikan kepada karyawan bertujuan untuk mendorong prestasi kerja karyawan dan menentukan besarnya kompensasi yang akan diterima oleh setiap karyawan.

Berdasarkan dari beberapa pengertian dari para ahli, maka dapat disimpulkan kompensasi merupakan segala bentuk imbalan atau balas jasa yang diberikan perusahaan 
dan diterima oleh karyawan atas kerja yang telah dilakukan, seperti dalam pemberian uang, pemberian material dan fasilitas, dan dalam bentuk kesempatan berkarier.

\section{Model Penelitian}

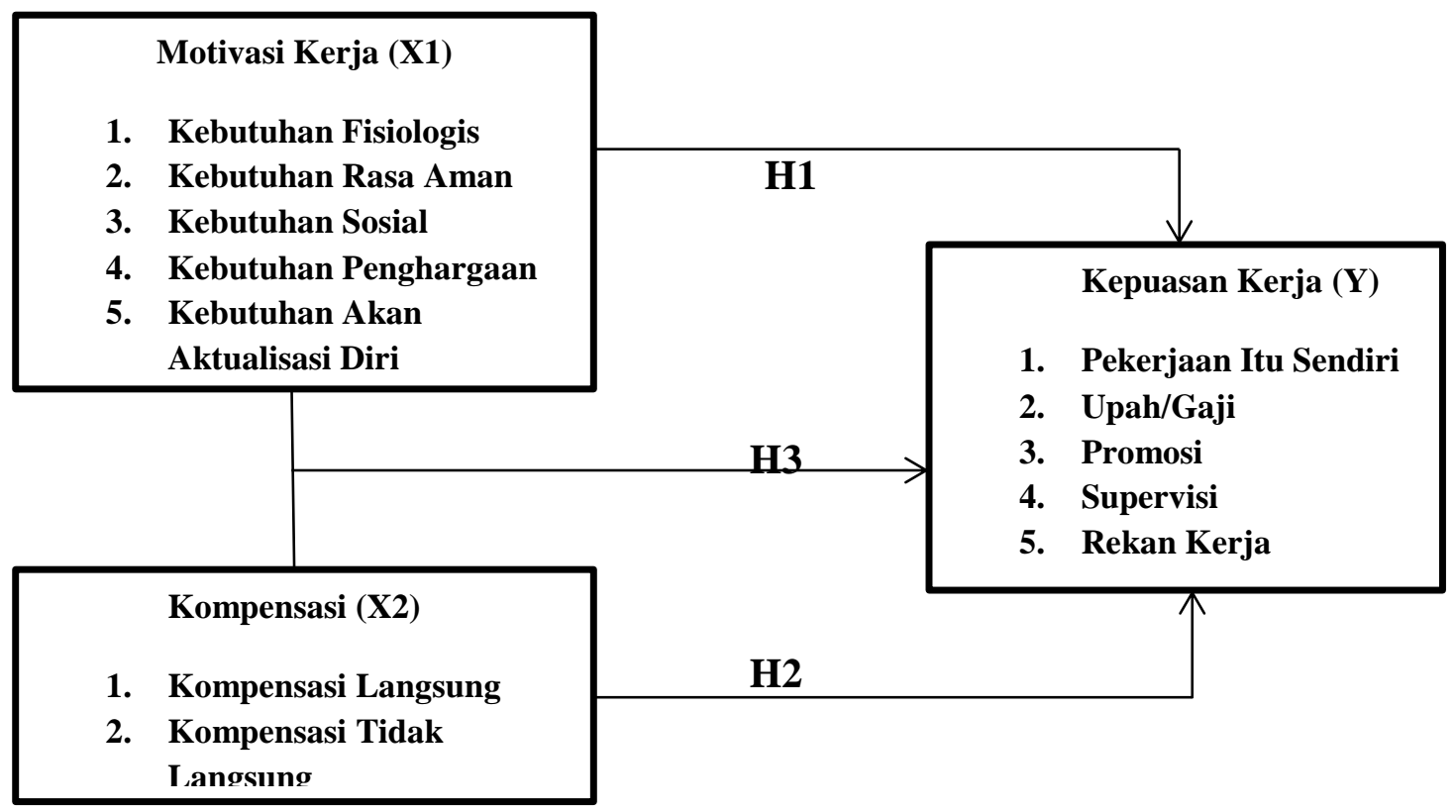

Gambar 1. Model Penelitian

Sumber: data diolah oleh peneliti, 2017

\section{Hipotesis}

Berdasarkan kajian pustaka dan kerangka pemikiran di atas, maka penjabaran hipotesis sebagai berikut:

\section{Hipotesis 1 (H1)}

Ho : Motivasi Kerja tidak berpengaruh terhadap kepuasan kerja karyawan PT Tridaya Eramina Bahari.

Ha : Motivasi Kerja berpengaruh terhadap kepuasan kerja karyawan PT Tridaya Eramina Bahari.

\section{Hipotesis 2 (H2)}

Ho : Kompensasi tidak berpengaruh terhadap kepuasan kerja karyawan PT Tridaya Eramina Bahari. 
Ha: Kompensasi berpengaruh terhadap kepuasan kerja karyawan PT Tridaya Eramina Bahari.

\section{Hipotesis 3 (H3)}

Ho : Motivasi kerja dan kompensasi tidak dapat memprediksi kepuasan kerja karyawan PT Tridaya Eramina Bahari.

Ha : Motivasi kerja dan kompensasi dapat memprediksi kepuasan kerja karyawan PT Tridaya Eramina Bahari.

\section{METODE PENELITIAN}

Penelitian menggunakan metode deskriptif dan explanatory. Data yang digunakan dalam penelitian ini berasal dari data primer yang didapatkan melalui wawancara dan kuesioner, sedangkan data sekunder didapatkan dari buku-buku, jurnal dan skripsi dari penelitian terdahulu. Metode pengambilan sampel menggunakan convenience sampling. Jumlah sampel yang digunakan dalam penelitian ini sebanyak 70 responden dati total populasi yang berjumlah 85 karyawan PT Tridaya Eramina Bahari.

\section{HASIL DAN PEMBAHASAN}

\section{Hasil Uji Instrumen}

\section{Hasil Uji Validitas}

Uji validitas digunakan untuk mengukur valid atau tidaknya suatu instrumen dalam penelitian. Instrumen yang digunakan adalah kuesioner yang di uji coba pada 30 responden karyawan PT Tridaya Eramina Bahari. Hasil uji validitas dapat dilihat pada Tabel 3. dibawah ini:

Tabel 3. Hasil Uji Validitas

\begin{tabular}{cccc}
\hline Variabel & Item sebelum diuji & Item tidak valid & Item valid \\
\hline Kepuasan Kerja & & & \\
Motivasi Kerja & 12 & 0 & 12 \\
Kompensasi & 10 & 0 & 10 \\
\hline
\end{tabular}

Sumber: Data diolah oleh peneliti, 2017

Berdasarkan Tabel 3, uji validitas yang dilakukan pada variabel kepuasan kerja, motivasi kerja, dan kompensasi dapat terlihat seluruh butir pernyataan dalam variabel 
tersebut valid karena memiliki rhitung $>$ rtabel. Dikatakan valid karena instrumen yang digunakan dalam penelitian telah memenuhi syarat, yaitu nilai $r_{h i t u n g}>r_{\text {tabel }} 0,361$.

\section{Hasil Uji Reliabilitas}

Uji reliabilitas digunakan untuk mengetahui derajat kecepatan, ketelitian, atau keakuratan yang ditunjukkan oleh instrumen pengukuran.Hasil uji reliabilitas untuk masing-masing variabel dapat dilihat pada Tabel 4. Berikut ini:

Tabel 4. Hasil Uji Reliabilitas

\begin{tabular}{lcc}
\hline \multicolumn{1}{c}{ Variabel } & Alpha Cronbach & Keterangan \\
\hline Kepuasan Kerja (Y) & 0,914 & Reliabel \\
Motivasi Kerja (X1) & 0,842 & Reliabel \\
Kompensasi (X2) & 0,781 & Reliabel \\
\hline
\end{tabular}

Sumber: Data diolah oleh peneliti, 2017

Berdasarkan Tabel 4, dapat terlihat untuk masing-masing variabel kepuasan kerja, motivasi, dan pengembangan karir memiliki nilai Alpha Croncbach > 0,6, yaitu 0.901, 0,881, dan 0.917. Jadi instrumen ketiga variabel dapat dinyatakan reliabel atau dapat dipercaya karena nilai Alpha Cronbach lebih dari 0,6.

\section{Hasil Analisis Deskriptif}

Deskriptif data adalah hasil pengolahan data mentah berupa variabel penelitian yang bertujuan untuk memberikan gambaran secara umum mengenai penyebaran dan distribusi data. Data yang diperoleh dari penelitian ini didapat dari hasil penyebaran kuesioner yang disebarkan kepada sampel 70 karyawan PT Tridaya Eramina Bahari. Bobot skoring masing-masing variabel dapat dilihat sebagai berikut:

Tabel 5. Bobot Skor Kriteria Variabel

\begin{tabular}{|c|c|c|c|}
\hline & $\begin{array}{c}\text { Kepuasan } \\
\text { Kerja }\end{array}$ & $\begin{array}{c}\text { Motivasi } \\
\text { Kerja }\end{array}$ & Kompensasi \\
\hline $1.00 \%-25.00 \%$ & Sangat Tidak Puas & Sangat Rendah & Sangat Tidak Layak \\
\hline $25.01 \%-50.00 \%$ & Kurang Puas & Rendah & Kurang Layak \\
\hline $50.01 \%-75.00 \%$ & Puas & Tinggi & Layak \\
\hline $75.01 \%-100.00 \%$ & Sangat Puas & Sangat Tinggi & Sangat Layak \\
\hline
\end{tabular}

Sumber: Data diolah oleh peneliti, 2017

Hasil analisis deskriptif untuk masing-masing variabel dapat dilihat pada Tabel 6 . berikut ini: 
Tabel 6. Nilai Analisis Deskriptif

\begin{tabular}{cccc}
\hline & $\begin{array}{c}\text { Kepuasan } \\
\text { Kerja }\end{array}$ & $\begin{array}{c}\text { Motivasi } \\
\text { Kerja }\end{array}$ & Kompensasi \\
\hline Sangat Setuju & $27,3 \%$ & $27 \%$ & $25,5 \%$ \\
Setuju & $27 \%$ & $26 \%$ & $26,1 \%$ \\
Netral & $20,1 \%$ & $22,5 \%$ & $11,5 \%$ \\
Tidak Setuju & $19 \%$ & $18,5 \%$ & $25,5 \%$ \\
Sangat Tidak Setuju & $5,4 \%$ & $6,5 \%$ & $12 \%$ \\
\hline
\end{tabular}

Sumber: Data diolah oleh peneliti, 2017

Pada Tabel 6 dapat dilihat persentase jawaban yang diberikan oleh para responden yang menggambarkan setiap variabel. Pada variabel kepuasan kerja, dapat dilihat bahwa responden menjawab setuju sebesar $27 \%$ dan sangat setuju $27,3 \%$. Jika dibandingkan dengan kriteria bobot skoring maka dapat disimpulkan bahwa kepuasan kerja karyawan termasuk ke dalam kriteria kurang puas. Kontribusi terbesar untuk jawaban tidak setuju terdapat pada dimensi upah/gaji dan dimensi promosi. Dapat disimpulkan bahwa kepuasan kerja karyawan yang masuk ke dalam kriteria kurang puas dikarenakan karyawan merasa belum mendapat kesempatan promosi jabatan dan kesempatan promosi di dalam perusahaan belum diterapkan dengan baik, karyawan juga merasa gaji yang mereka terima belum sesuai dengan beban kerja mereka.

Pada variabel motivasi kerja, hasil jawaban responden menjawab setuju sebesar $26 \%$ dan sangat setuju 27\%. Jika dibandingkan dengan kriteria bobot skoring dapat disimpulkan bahwa motivasi kerja karyawan termasuk ke dalam kriteria rendah. Kontribusi terbesar untuk jawaban tidak setuju terdapat pada dimensi kebutuhan fisiologis dan dimensi kebutuhan penghargaan. Dapat disimpulkan bahwa motivasi kerja karyawan termasuk dalam kriteria rendah dikarenakan karyawan merasa belum terpenuhi kebutuhan fisiologis mereka yaitu kebutuhan sandang dan kebutuhan rumah mereka dan juga karyawan merasa belum mendapatkan penghargaan atas prestasi kerja mereka.

Selanjutnya, pada variabel kompensasi hasil jawaban responden menjawab setuju sebesar $26,1 \%$ dan sangat setuju sebesar 25,5\%. Jika dilihat dari mayoritas jawaban responden maka dapat disimpulkan bahwa kompensasi karyawan termasuk ke dalam kriteria kurang layak. Hal ini disebabkan pada dimensi kompensasi langsung dan juga pada dimensi kompensasi tidak langsung. Dapat disimpulkan bahwa karyawan merasa 
gaji yang mereka terima belum sesuai dengan upah minimum yang ditetapkan pemerintah, karyawan belum mendapatkan insentif jika hasil kerja mereka melebihi target yang ditetapkan perusahaan dan tidak mendapatkan asuransi dalam bekerja juga turut mempengaruhi kepuasan karyawan terhadap kompensasi yang mereka terima selama ini.

\section{Hasil Uji Asumsi Klasik}

\section{Hasil Uji Normalitas}

Uji normalitas bertujuan untuk mengetahui apakah sampel yang diambil dalam penelitian terdistribusi secara normal atau tidak. Uji normalitas menggunakan One Sample Kolmogrov-Smirnov Test dan dikatakan normal jika nilai residual yang terdistribusi secara normal memiliki probabilitas signifikan lebih dari 0,05.

Tabel 7. Hasil Uji Normalitas

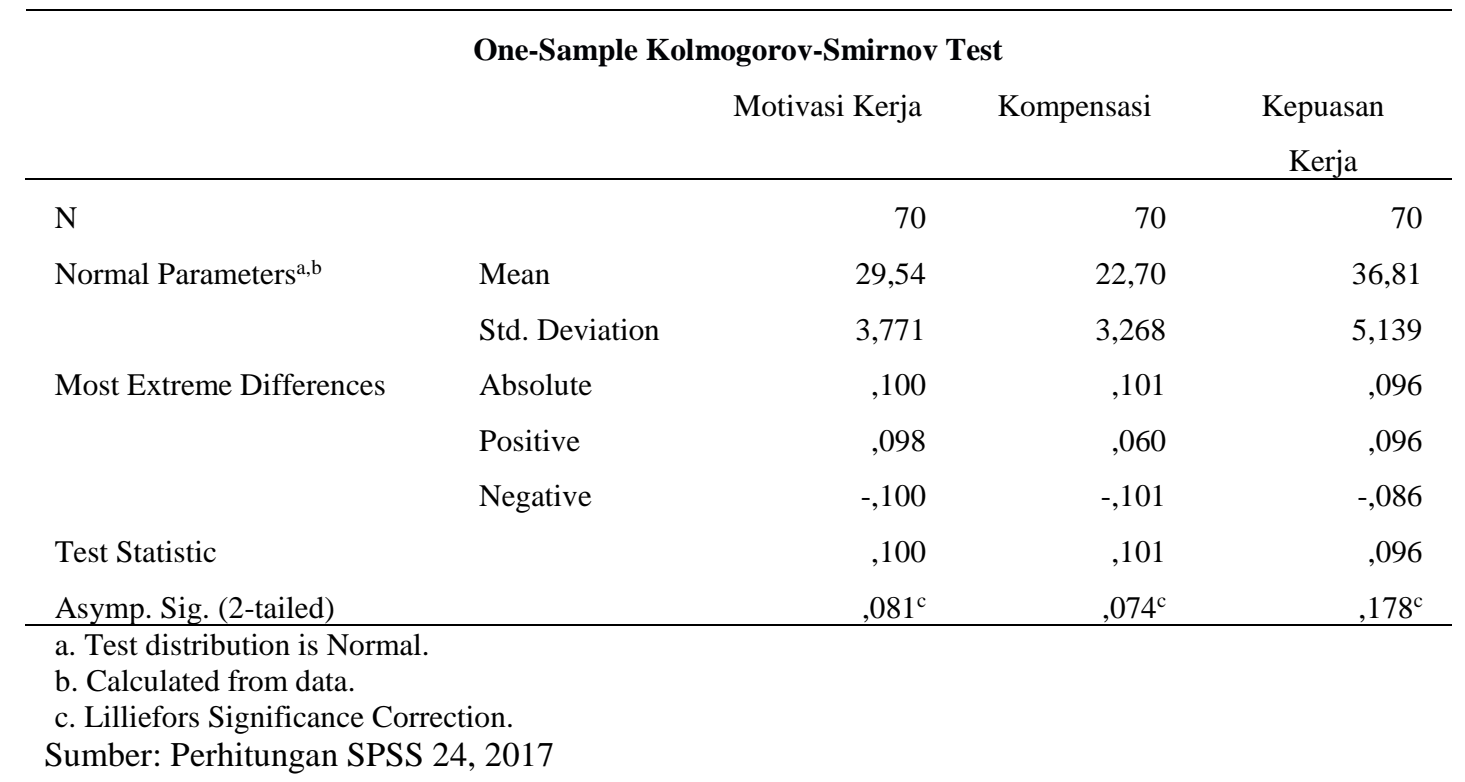

Berdasarkan Tabel 7 yang dilakukan dengan menggunakanprogram SPSS 24 uji normalitas dengan menggunakan Kolmogrov Smirnov, dapat menunjukkan hasil signifikan variabel kepuasan kerja sebesar 0,178, variabel motivasi kerja sebesar 0,081 dan variabel kompensasi sebesar 0,074. Ketiga angka signifikan tersebut lebih besar dari 0,05, maka dapat dikatakan data terdistribusi normal dan memenuhi syarat dilakukan metode analisis regresi linear berganda. 


\section{Hasil Uji Linearitas}

Uji linearitas bertujuan untuk mengetahui apakah dua variabel mempunyai hubungan yang linear atau tidak secara signifikan. Uji linearitas dilakukan dengan menggunakan test for linearity pada taraf signifikan 0,05. Kriteria dalam uji linearitas ini dua variabel dikatakan mempunyai hubungan yang linear bila signifikan (linearity) kurang dari 0,05 .

Tabel 8. Hasil Uji Linearitas Motivasi Kerja dan Kepuasan Kerja

\begin{tabular}{|c|c|c|c|c|c|c|c|}
\hline \multicolumn{8}{|c|}{ ANOVA Table } \\
\hline \multirow[b]{3}{*}{ Kepuasan Kerja * } & \multirow[b]{3}{*}{ Between } & \multirow[b]{3}{*}{ (Combined) } & \multirow{3}{*}{$\begin{array}{l}\text { Sum of } \\
\text { Squares } \\
778,008\end{array}$} & \multirow{3}{*}{$\begin{array}{l}\text { df } \\
16\end{array}$} & \multirow{3}{*}{$\begin{array}{c}\text { Mean } \\
\text { Square } \\
48,626\end{array}$} & \multirow{3}{*}{$\begin{array}{c}\mathrm{F} \\
2,467\end{array}$} & \multirow{3}{*}{$\begin{array}{l}\text { Sig. } \\
\text {,007 }\end{array}$} \\
\hline & & & & & & & \\
\hline & & & & & & & \\
\hline \multirow[t]{5}{*}{ Motivasi Kerja } & Groups & Linearity & 605,815 & 1 & 605,815 & 30,738 &, 000 \\
\hline & & Deviation & 172,194 & 15 & 11,480 &, 582 & ,875 \\
\hline & & from Linearit & & & & & \\
\hline & \multicolumn{2}{|c|}{ Within Groups } & 1044,577 & 53 & 19,709 & & \\
\hline & \multicolumn{2}{|l|}{ Total } & 1822,586 & 69 & & & \\
\hline
\end{tabular}

Sumber: Perhitungan SPSS 24, 2017

Berdasarkan hasil uji linearitas antara variabel motivasi dengan kepuasan kerja pada Tabel 8 diatas, dapat diketahui bahwa nilai signifikan linearity sebesar 0,000. Nilai signifikan tersebut kurang dari 0,05, sehingga dapat disimpulkan bahwa antara kedua variabel tersebut terdapat hubungan yang linier.

Tabel 8. Hasil Uji Linearitas Kompensasi dan Kepuasan Kerja

\begin{tabular}{|c|c|c|c|c|c|c|c|}
\hline \multicolumn{8}{|c|}{ ANOVA Table } \\
\hline \multirow{6}{*}{$\begin{array}{l}\text { Kepuasan Kerja } \\
\text { * Kompensasi }\end{array}$} & & & $\begin{array}{l}\text { Sum of } \\
\text { Squares }\end{array}$ & $\mathrm{df}$ & $\begin{array}{l}\text { Mean } \\
\text { Square }\end{array}$ & $\mathrm{F}$ & Sig. \\
\hline & Between & (Combined) & 776,185 & 15 & 51,746 & 2,670 & ,004 \\
\hline & Groups & Linearity & 631,547 & 1 & 631,547 & 32,591 & ,000 \\
\hline & & $\begin{array}{l}\text { Deviation } \\
\text { from Linearity }\end{array}$ & 144,638 & 14 & 10,331 &, 533 & ,902 \\
\hline & Within Groups & & 1046,401 & 54 & 19,378 & & \\
\hline & Total & & 1822,586 & 69 & & & \\
\hline
\end{tabular}

Sumber: Perhitungan SPSS 24, 2017

Berdasarkan hasil uji linearitas antara variabel pengembangan karir dengan variabel kepuasan kerja pada Tabel 8 diatas, dapat diketahui bahwa nilai signifikan 
linearity sebesar 0,000. Nilai signifikan tersebut kurang dari 0,05, sehingga dapat disimpulkan bahwa antara kedua variabel tersebut terdapat hubungan yang linier.

\section{Hasil Uji Multikolinearitas}

Uji multikolinearitas bertujuan untuk mengetahui apakah pada model regresi ditemukan korelasi kuat antar variabel bebas (independen). Uji multikolinearitas dilakukan dengan SPSS dengan melihat nilai VIF (variance inflation factor) dan koefisien korelasi antar variabel bebas.

Tabel 9. Hasil Uji Multikolinearitas

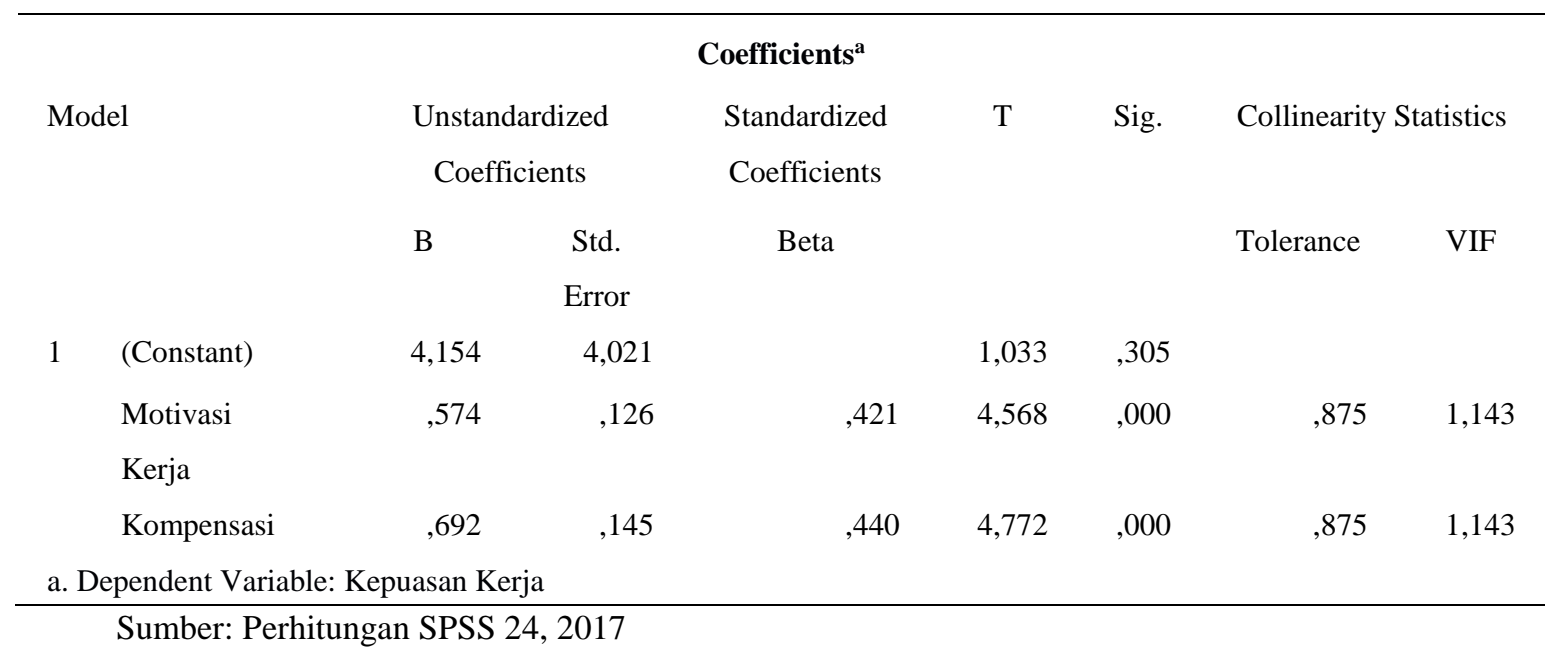

Berdasarkan hasil uji multikolinearitas pada Tabel 9, dapat diketahui angka VIF untuk motivasi sebesar 1.143, dan angka VIF untuk pengembangan karir sebesar 1.143. Nilai VIF kedua variabel kurang dari 5 dan mendekati 1, maka diantara kedua variabel bebas tersebut tidak ditemukan adanya masalah multikolinearitas.

\section{Uji Heteroskedastisitas}

Uji heteroskedastisitas dilakukan untuk mengetahui apakah dalam sebuah model regresi terjadi ketidaksamaan varian dari residual suatu pengematan ke pengematan lain. Metode yang digunakan dalam penelitian ini adalah metode uji Spearman's Rho, yaitu metode untuk mengkorelasi nilai residual dengan masing-masing variabel bebas. 
Tabel 10. Hasil Uji Heteroskedastisitas

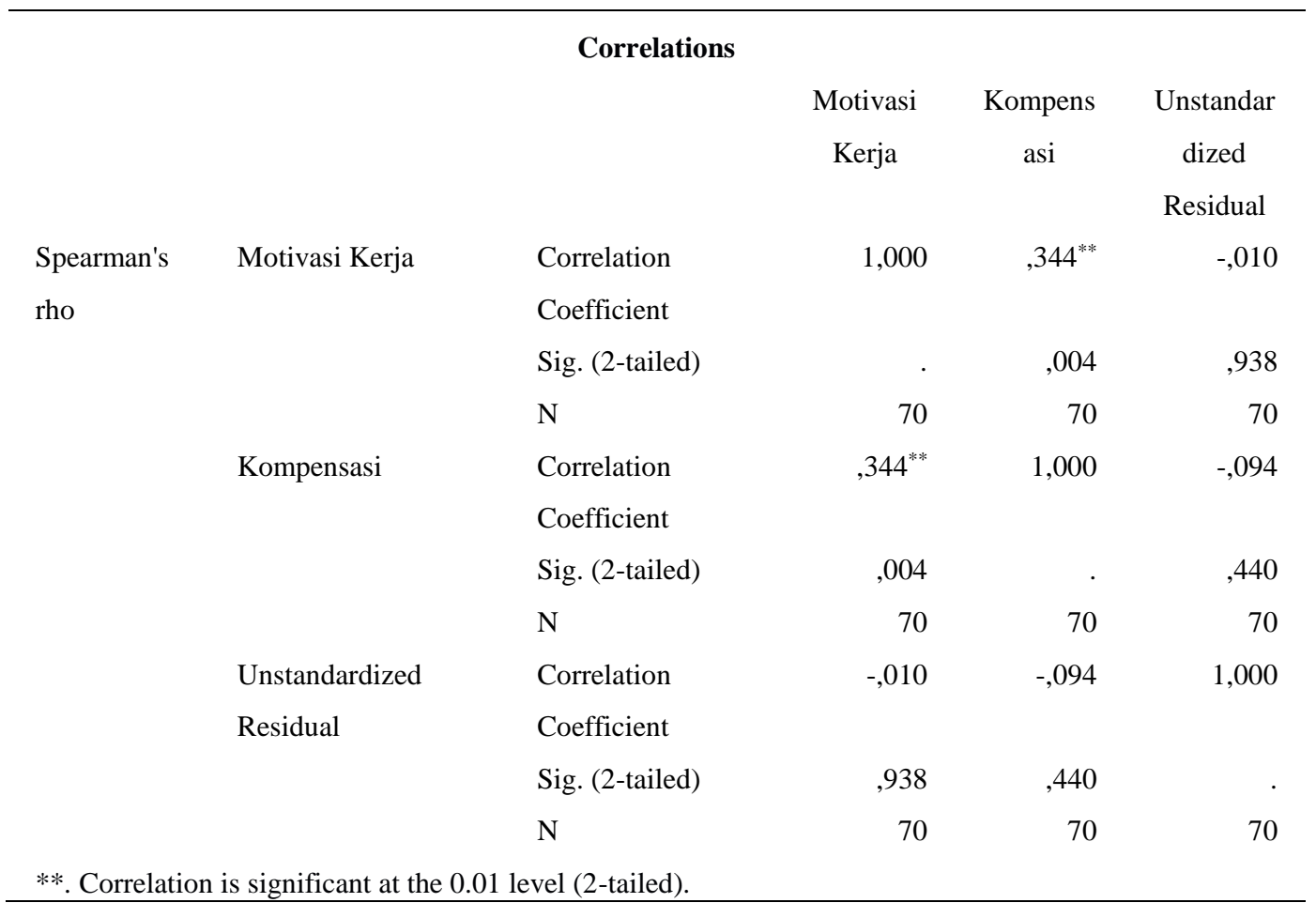

Sumber: Perhitungan SPSS 24, 2017

Pada Tabel 10 diatas, dapat diketahui korelasi antara motivasi dengan unstandardized residual menghasilkan nilai signifikan sebesar 0,938 dan korelasi antara pengembangan karir dengan unstandardized residual menghasilkan nilai signifikan sebesar 0,440. Jadi, dapat disimpulkan bahwa pada model regresi tidak ditemukan adanya masalah heterokedastisitas, hal ini karena nilai signifikan korelasi lebih besar dari 0,05 .

\section{Hasil Uji Regresi Linear Berganda}

\section{Hasil Uji t}

Tabel 11. Uji t Variabel Motivasi Kerja

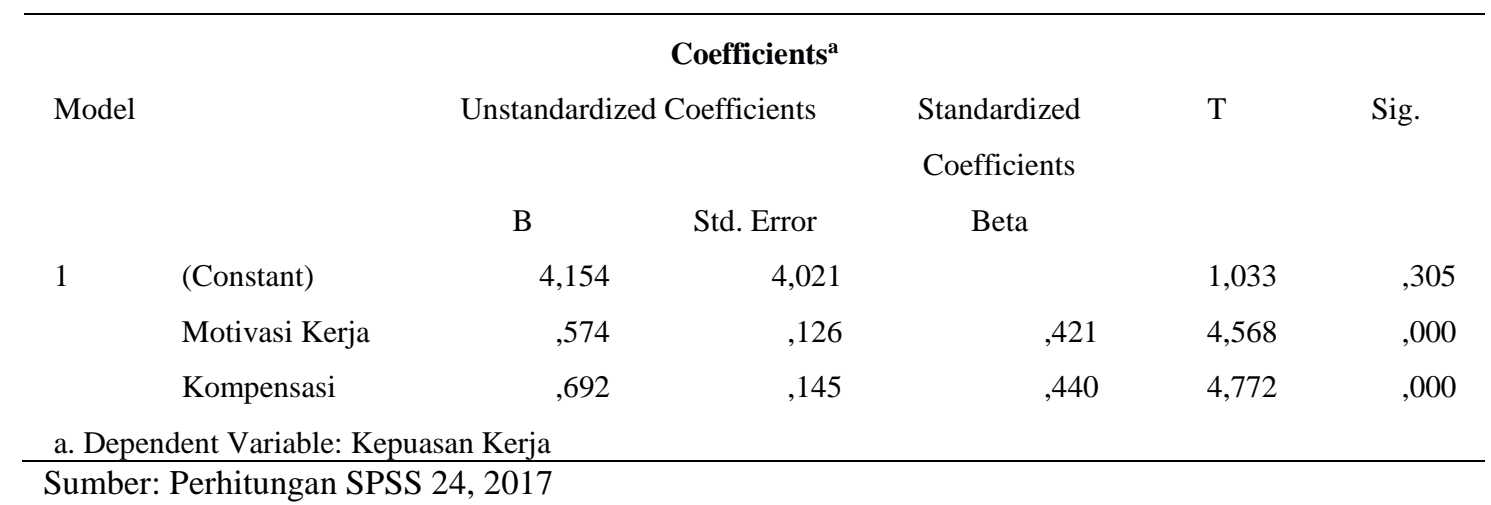




\section{Hipotesis 1 (H1)}

Ho : Motivasi Kerja tidak berpengaruh terhadap kepuasan kerja karyawan PT Tridaya Eramina Bahari.

Ha : Motivasi Kerja berpengaruh terhadap kepuasan kerja karyawan PT Tridaya Eramina Bahari.

Untuk menguji hipotesis diperlukan $\mathrm{t}$ tabel sebagai pembanding. $\mathrm{T}$ tabel dicari dengan $\alpha=5 \%: 2=2,5 \%$ (uji 2 sisi) dengan df =n-k-1 atau 70-2-1, dimana n adalah jumlah sampel dan $\mathrm{k}$ adalah jumlah variabel bebas. Berdasarkan perhitungan tersebut didapat tabel sebesar 1,996. Berdasarkan Tabel 11, variabel motivasi kerja memiliki thitung sebesar 4,568. Dengan demikian thitung $(4,568)>t_{\text {tabel }}(1,996)$ serta nilai signifikansi $0,000<0,05$. Maka dapat disimpulkan dari hipotesis 1 bahwa Ho dan Ha diterima yaitu motivasi kerja berpengaruh positif dan signifikan terhadap kepuasan kerja karyawan PT Tridaya Eramina Bahari.

Hasil ini sesuai dengan teori yang ada yaitu, teori dua faktor dari Herzberg. Herzberg membedakan dua faktor yang mempengaruhi motivasi para pekerja dengan cara berbeda, faktor hygiene dan faktor motivator. Faktor hygiene yaitu serangkaian kondisi ekstrinsik yaitu keadaan pekerjaan dan kondisi ini tidak ada sehingga tidak perlu memotivasi karyawan, faktor ini meliputi upah, keamanan kerja, kondisi kerja dan hygienic, status dan prosedur perusahaan. Faktor motivator mencakup faktor-faktor yang berkaitan dengan isi pekerjaan, yang merupakan faktor intrinsik dari pekerjaan yaitu, tanggung jawab, kemajuan, pekerjaan itu sendiri, pencapaian prestasi, dan pengakuan. Faktor motivator menyebabkan seseorang bergerak dari keadaan tidak puas kepada kepuasan.

Hasil ini sesuai dengan penelitian yang dilakukan oleh Awang Mada Kurnia, Bambang Swasto Sunuharyo, Hamidah Nayati Utami (2013) memiliki kontribusi sebesar 52,4\%, dapat diartikan 52,4\% kepuasan kerja dijelaskan oleh variabel motivasi kerja. Selanjutnya penelitian Titin Hidayati Maghfiroh (2013) memiliki kontribusi sebesar $72.5 \%$, dapat diartikan 72,5\% kepuasan kerja dijelaskan oleh variabel motivasi keja. Berdasarkan penelitian terdahulu dibuktikan juga bahwa motivasi kerja berpengaruh positif terhadap kepuasan kerja karyawan. 


\section{Hipotesis 2 (H2)}

Ho : $\quad$ Kompensasi tidak berpengaruh terhadap kepuasan kerja karyawan PT Tridaya Eramina Bahari.

Ha : Kompensasi berpengaruh terhadap kepuasan kerja karyawan PT Tridaya Eramina Bahari.

Pada Tabel 11 juga menunjukkan nilai thitung untuk variabel kompensasi sebesar 4,772, serta nilai signifikansi sebesar 0,000. Hal tersebut menunjukkan bahwa thitung>

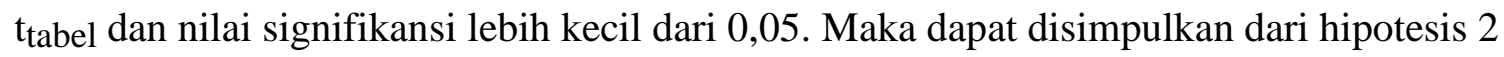
bahwa H0 dan Ha diterima yaitu kompensasi memiliki pengaruh positif dan signifikan terhadap kepuasan kerja kerja karyawan PT Tridaya Eramina Bahari.

Hal ini sesuai teori ekuitas yang menjelaskan sebab-sebab kepuasan atau ketidakpuasan. Menurut Lawler, perbedaan antara jumlah yang diterima oleh karyawan dan jumlah yang mereka duga diterima oleh orang lain merupakan penyebab langsung kepuasan kerja. Adapun teori lain yang menyatakan hubungan kompensasi dengan kepuasan kerja yaitu discrepancy theory (teori perbedaan). Discrepancy theory merupakan cara mengukur kepuasan kerja seseorang dengan menghitung selisih antara apa yang seharusnya dengan kenyataan yang dirasakan.

Hal tersebut didukung oleh penelitian I Gede Mahendrawan dan Ayu Desi Indrawati (2015) kompensasi berpengaruh terhadap kepuasan kerja, hal ini sejalan dengan Mardahleni (2013) memiliki kontribusi sebesar 22\%, dapat diartikan 22\% kepuasan kerja dijelaskan oleh variabel kompensasi. Selanjutnya penelitian Sinollah (2011) memiliki kontribusi sebesar $24,8 \%$, dapat diartikan $24,8 \%$ kepuasan kerja dijelaskan oleh variabel kompensasi. Berdasarkan penelitian terdahulu menyatakan bahwa kompensasi mempunyai pengaruh terhadap kepuasan kerja, artinya apabila kompensasi diberikan secara wajar dan adil, maka akan menyebabkan kepuasan kerja karyawan meningkat. 


\section{Hasil Uji F (Uji Kelayakan Model)}

\section{Hipotesis 3 (H3)}

Ho : Motivasi kerja dan kompensasi tidak dapat memprediksi kepuasan kerja karyawan PT Tridaya Eramina Bahari.

Ha : Motivasi kerja dan kompensasi dapat memprediksi kepuasan kerja karyawan PT Tridaya Eramina Bahari.

Tabel 12. Hasil Uji F

\begin{tabular}{rrrrrrr}
\hline \multicolumn{7}{c}{ MNOVA $^{\mathbf{a}}$} \\
Model \\
1 & & Sum of Squares & Df & Mean Square & F & \multicolumn{1}{c}{ Sig. } \\
& Regression & 914,440 & 2 & 457,220 & 33,732 &, $000^{\mathrm{b}}$ \\
& Residual & 908,146 & 67 & 13,554 & & \\
& Total & 1822,586 & 69 & &
\end{tabular}

a. Dependent Variable: Kepuasan Kerja

b. Predictors: (Constant), Kompensasi, Motivasi Kerja

Sumber: Perhitungan SPSS 24, 2017

Pada tabel 12, Fhitung yang diperoleh sebesar 33,732. Nilai $F_{\text {hitung }}>F_{\text {tabel, }}$ yang dicari dengan $\alpha=5 \%$, df1 $=\mathrm{k}-1$ atau 3-1 = 2 dan df2 (n-k) atau 70-3=67 (k= jumlah variabel). Menghasilkan $F_{\text {tabel }}$ sebesar 3,134. Berdasarkan perhitungan tersebut, didapat

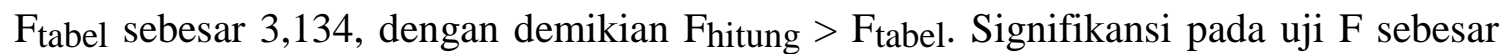
0,000; dengan demikian lebih kecil dari 0,05. Kesimpulan yang dapat diambil adalah $\mathrm{H}_{\mathrm{O}}$ ditolak atau variabel independen motivasi kerja dan kompensasi berpengaruh terhadap variabel dependen kepuasan kerja.

Hal ini sejalan dengan penelitian yang dilakukan sebelumnya oleh Sudarno, Priyono, Dinda Sukmaningrum (2016), Ikmal Nur Muflih (2015) 19,5\%, dapat diartikan 24,8\% kepuasan kerja dijelaskan oleh variabel motivasi kerja dan kompensasi. Ni Ketut Ayu Juli Astuti dan I Nyoman Sudarma (2013) yang menyatakan motivasi kerja dan kompensasi secara bersama sama berpengaruh terhadap kepuasan kerja. Hal ini berarti jika motivasi kerja ditingkatkan dan kompensasi diberikan secara wajar dan adil, maka dapat tercapainya kepuasan kerja yang tinggi. 


\section{Hasil Analisis Koefisien Determinasi}

Tabel 13. Hasil Uji Koefisien Determinasi

\begin{tabular}{lccr}
\hline \multicolumn{2}{c}{ Model Summary } \\
Model & R Square & Adjusted R Square & $\begin{array}{r}\text { Std. Error of the } \\
\text { Estimate }\end{array}$ \\
1 &, $708^{\mathrm{a}}$ &, 502 & 3,682 \\
a. Predictors: (Constant), Kompensasi, Motivasi Kerja & \\
b. Dependent Variable: Kepuasan Kerja & \\
\hline Sumber: Perhitungan SPSS 24, 2017
\end{tabular}

Dari Tabel 13, nilai $\mathrm{R}^{2}$ sebesar 0,502 atau (50,2\%). Hal ini menunjukkan bahwa 50,2\% kepuasan kerja dijelaskan oleh faktor motivasi kerja dan kompensasi sedangkan sisanya sebesar $49,8 \%$ dijelaskan oleh variabel lain.

\section{KESIMPULAN DAN SARAN}

\section{Kesimpulan}

Berdasarkan dari hasil penelitian mengenai "Pengaruh Motivasi Kerja dan Kompensasi Terhadap Kepuasan Kerja Pada Karyawan PT Tridaya Eramina Bahari”, maka dapat disimpulkan sebagai berikut:

1. Deskripsi motivasi kerja, kompensasi dan kepuasan kerja pada karyawan PT Tridaya Eramina Bahari adalah:

a. Motivasi kerja pada karyawan PT Tridaya Eramina Bahari termasuk dalam kriteria rendah.

b. Kompensasi pada karyawan PT Tridaya Eramina Bahari termasuk dalam kriteria kurang layak.

c. Kepuasan kerja pada karyawan PT Tridaya Eramina Bahari termasuk dalam kriteria kurang puas.

2. Motivasi kerja memiliki pengaruh positif dan signifikan terhadap kepuasan kerja pada karyawan PT Tridaya Eramina Bahari. Jika motivasi kerja meningkat, maka kepuasan kerja juga akan meningkat.

3. Kompensasi memiliki pengaruh positif dan signifikan terhadap kepuasan kerja pada karyawan PT Tridaya Eramina Bahari. Jika kompensasi dalam perusahaan meningkat, maka kepuasan kerja juga akan meningkat. 
4. Motivasi kerja dan kompensasi dapat memprediksi kepuasan kerja pada karyawan PT Tridaya Eramina Bahari.

\section{Saran Untuk PT Tridaya Eramina Bahari}

Berdasarkan kesimpulan yang telah dijelaskan diatas, ada beberapa saran yang dapat diajukan dalam penelitian ini adalah sebagai berikut:

1. Perusahaan sebaiknya menaikkan gaji karyawan sesuai dengan Upah Minimum Regional Jakarta tahun 2017 yaitu sebesar Rp. 3.350.000, jika perusahaan mempunyai banyak pertimbangan dalam menaikkan gaji sesuai dengan UMR Jakarta 2017 maka perusahaan dapat menaikkan gaji karyawan sesuai dengan UMR Jakarta 2016 sebesar Rp. 3.100.000.

2. Perusahaan sebaiknya memberikan kesempatan kepada karyawan untuk dapat meningkatkan posisi jabatan kerja mereka dengan menerapkan kebijakan promosi seperti memberikan kesempatan kenaikan jabatan dengan syarat jika karyawan yang memiliki hasil kerja yang terus meningkat selama satu atau dua tahun dan dengan masa kerja yang sudah cukup lama selama 10 tahun hingga lebih dari 10 tahun.

3. Perusahaan dapat memberikan penghargaan atas hasil kerja karyawan yang tepat waktu dengan adanya hadiah berupa produk perusahaan untuk karyawan. PT Tridaya Eramina Bahari merupakan perusahaan dibidang perikanan, maka perusahaan dapat memberikan 3 sampai 5 ikan untuk karyawan.

4. Memberikan asuransi kesehatan kepada karyawan berupa asuransi BPJS yaitu sebesar $4 \%$ dibayarkan oleh perusahaan sebagai benefit dan $1 \%$ dibayarkan oleh karaywan yang direduksi dari gaji, namun batas minimal perhitungan pembayaran berdasarkan Upah Minimum Regional.

5. Memberikan insentif untuk karyawan yang bekerja melebihi target yang ditetapkan yaitu berupa uang tambahan sebesar 5 sampai $10 \%$ dari gaji mereka.

\section{DAFTAR PUSTAKA}

Ahmad, Naveed; Nadeem Iqbal, dan Naqvi Hamad. (2014). Impact of Organizational Commitment and Employee Performance on The Employee Satisfaction, 
Pakistan. International Journal of Learning, Teaching and Educational Research, Vol.1, No.1, h.85.

Astuti, Ni Ketut Ayu Juli; dan I Nyoman Sudarma. (2013). Pengaruh Kompensasi dan Motivasi Terhadap Kepuasan Kerja dan Kinerja Karyawan Pada Hotel Bakung’s Beach Cottages Kuta Bali. Jurnal.

Badriyah, Mila. (2015). Manajemen Sumber Daya Manusia. Bandung: Pustaka Setia.

Ghozali, Imam. (2013). Aplikasi Analisis. Semarang: Badan Penerbit Undip.

Kadarisman. (2012). Manajemen Pengembangan Sumber Daya Manusia. Jakarta: PT. Rajagrafindo Persada.

Kuncoro, Mudrajad. (2011). Metode Kuantitatif. Yogyakarta: Unit Sekolah Tinggi Ilmu Manajemen YKPN.

Musfiqon. (2012). Panduan Lengkap Metode Penelitian Pendidikan. Jakarta: Prestasi Pustakaraya.

Pinder, Craig C. (2008). Work Motivation Organizational Behavior. New York: Psychology Press.

Priansa, Donni Junni. (2014). Perencanaan \& Pengembangan SDM. Bandung: Alfabeta. Priyatno, Duwi. (2010). Teknik Mudah \& Cepat Melakukan Analisis Data Penelitian dengan SPSS dan Tanya Jawab Ujian Pendadaran. Yogyakarta: Gaya Media.

Siregar, Syofian. (2012). Statistika Deskriptif Untuk Penelitian. Jakarta: Rajawali Pers.

Subekhi, Akhmad; dan Mohammad Jauhar. (2012). Pengantar MSDM. Jakarta: Prestasi Pustakaraya.

Sugiyono. (2014). Metode Penelitian Kuantitatif, Kualitatif, dan $R \&$ D. Bandung: Alfabeta.

Sujarweni, Wiratna. (2014). Metodologi Penelitian. Yogyakarta: Pustaka Baru Press.

Sukandarrumidi. (2012). Metode Penelitian Petunjuk Praktis Untuk Peneliti Pemula. Yogyakarta: Gajah Mada University.

Sumanto. (2014). Teori \& Aplikasi Metode Penelitian. Yogyakarta: CAPS.

Sunyoto, Danang. (2013). Manajemen SDM. Yogyakarta: CAPS. (2011). Analisis Regresi \& Uji Hipotesis. Yogyakarta: CAPS.

Kurnia, Awang Mada; Bambang Swasto Sunuharyo dan Hamidah Nayati Utami. (2013). Pengaruh Motivasi Kerja Terhadap Kepuasan Kerja dan Prestasi Kerja 
Karyawan (Studi Pada Karyawan PT. ASKES (Persero), Cabang Boyolali. Jurnal.

Maghfiroh, Titin Hidayati. (2013). Pengaruh Motivasi Kerja Terhadap Kepuasan Kerja Peagawai PT. PLN (PERSERO) Area Mojokerto. Jurnal.

Mahendrawan, I Gede; dan Ayu Desi Indrawati. (2015). Pengaruh Beban Kerja dan Kompensasi Terhadap Kepuasan Kerja PT. Panca Dewata Denpasar. Bali, EJurnal Manajemen Unud, Vol.4, No.11, h.3937.

Mardahleni. (2013). Pengaruh Kompensasi Terhadap Kepuasan Kerja Karyawan (Biro Distribusi dan Transportasi) Pada PT. Semen Padang. e-Jurnal Apresiasi Ekonomi.

Muflih, Ikmal Nur. (2015). Pengaruh Kompensasi dan Motivasi Kerja Terhadap Kepuasan Kerja Karyawan PT. Aseli Dagadu Djokdja. Skripsi.

Sudarno, Priyono; dan Dinda Sukmaningrum. (2016). Effect of Compensation, Motivation and Organizational Climate on Employee Satisfaction: Study on PT. Sumber Alfaria Trijaya Tbk. In Gedangan-Sidoarjo. International of Business and Management, Vol.11, No.2.

Sinollah. (2011). Pengaruh Kompensasi Terhadap Kepuasan Kerja Karyawan (Studi Pada PT. PLN (Persero) Distribusi Jawa Timur Ap \& J Pasuruan). Jurnal OTONOMI, Volume 11, No.1, h.1. 